\title{
Childbirth in the late 16th century
}

\author{
Lesley Smith
}

\section{Preparation for childbirth}

Preparation for childbirth in the 16th century amongst the merchant and aristocratic classes was a well-documented and structured affair. The gamble of producing an heir to secure a dynasty, or even a kingdom, made the business of successful childbirth extremely serious.

Great families would compete to give an outward show of providing the latest thinking in prenatal care. This was not only to impress the neighbours but also the in-laws, some of whom were likely to be present in the house, even if only in the form of a messenger.

For centuries it had been believed that rich and beautiful women, who led delicate lives, suffered very much more in childbirth than those lower down the social scale. Doxys (i.e. sexually initiated vagrants), whores and Rusticks were thought usually to have an easy birth before leaping to their feet and returning to their labours. Some poor souls no doubt did, but as hirelings they would have had little choice in the matter. Contemporary experts such as Pechey wrote: "for she that thinks to order an ordinary labouring, or country-woman like a person of quality, kills her".

It is fairly obvious why one might think that those involved in heavy physical work would be strong and therefore able to cope with the demands of childbirth, but extraordinary to think that people really believed beauty also meant fragility. In 1566 in Edinburgh Castle, Mary Queen of Scots perpetuated this myth with the birth of James VI (James I of England). Mary was of goddess proportions standing at 5 feet 11 inches tall, and a fantastic horsewoman, who drank eight pints of beer a day. She was also very beautiful and, yes, she had a very difficult childbirth. So difficult in fact that a witch was brought in to assist.

Once the lady of quality had considered and counted her dates she would prepare to withdraw from society, often living for weeks in one suite of rooms. This removal from public life took place for a number of reasons, but most particularly to avoid the noxious stench of humanity on the streets that might bring a poisonous miasma to her and her baby. It also meant the extremely heavy and restrictive clothing of the day need not be worn, but a shift and soft gown instead. We do, however, have a splendid painting of William Cecil's rather homely-faced wife, heavily pregnant in a magnificent black formal gown encrusted in gold that probably weighed around three stones.

Childbirth was essentially an all-female affair, although some state births do record that men were present. A selected band of ladies from the family and friends (sometimes enemies) would gather in the withdrawing room, often moving in completely, to prepare for the drama ahead. These ladies had the job of providing support, advice and encouragement, having themselves already experienced and survived the childbirth process. It was a sort of 'all hands on deck' approach.

\section{J Fam Plann Reprod Health Care 2007; 33(1): 63-64}

Tutbury Castle, Tutbury, UK

Lesley Smith, Curator

Correspondence to: Lesley Smith, Tutbury Castle, Tutbury, Staffordshire DE13 9JF, UK. E-mail: info@tutburycastle.com
They followed the Galenic principle of protecting the humours of the body and had the firm belief that boys were hotter. The withdrawing room was heavily shuttered and fires were kept burning in all weathers. Hangings were also used to keep out draughts. There was particular concern that cold air must not enter the open womb.

\section{Role of the midwife}

Midwives would be on standby either in the house or nearby. Throughout the mediaeval period, midwives were highly respectable and revered as both pious and worthy. For centuries they had been licensed by the bishops and worked under a strict regime. Their remit went further than one might imagine, for their licence stated that if a woman had a dead child or one that died within minutes, the midwife had the responsibility to bury the corpse "away from where animals might interfere". After this she was obliged to come back to the woman on a daily basis, take her hand, comfort her and encourage her to try again for another child. Midwives' respectability provided a decency precedent that would help avoid abortionists, changelings (i.e. often a poor child would be exchanged with one from a rich family for monetary gain) and even those who might murder a child for reward. It would also cut down the risk of incompetence through drunkenness.

By the time of the death of Elizabeth in March 1603, most midwives had slipped from their position of dignity and were regularly portrayed as vulgar and brutal in the later Hogarthian style. What happened to the 1400s dame

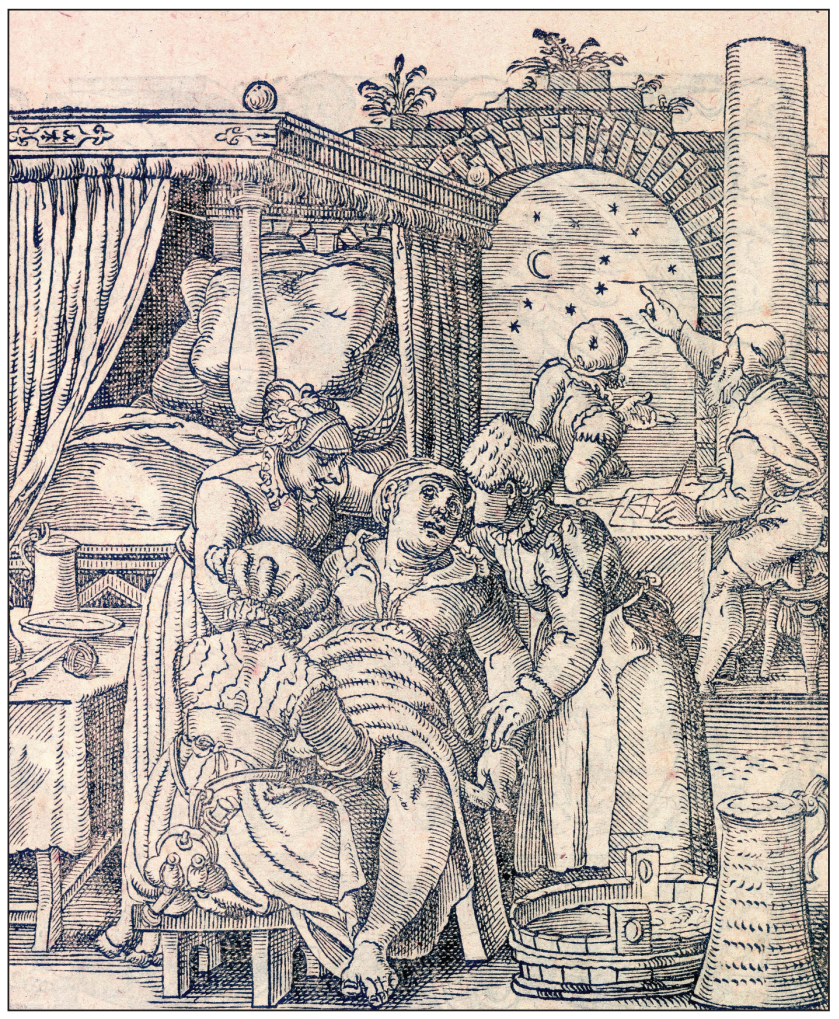

Figure 1 A woman, assisted by midwife and friends, gives birth. The men in the background are casting the child's horoscope. Figure reproduced, with permission, from Amman, Jost, Kunnst und Lehrbüchlein für die anfahenden Jungen Daraus reissen und Malen zu lernen, etc, Frankfurt, Germany; Feyrabends, 1580. (C) The British Library Board. All rights reserved (Shelfmark 683.e.16) 
in fine linen, that Women's Institute-type pillar of the community? The midwives' fall from grace was caused partly by bad press from the considerable competition, including female medical practitioners. The birth pangs of real science were on the horizon.

\section{Labour and delivery}

The commonest recommended method for bringing on a slow labour was to make the woman go up and down stairs and preferably shout out loud. I have no evidence as to whether the female entourage of helpers also accompanied the mother-to-be up and down the stairs offering advice and shouting, but it certainly seems possible. No wonder the husband was traditionally absent. I should think he was down at the alehouse and as far away as possible from this noisy domestic circus!

As the labour progressed, the woman was helped to the birthing stool, which seems to have been the most popular method for delivery. There is a much-reproduced drawing of a woman in the last stages of labour being assisted by a midwife (Figure 1). In the far room can been seen a stargazer in a star-spangled cloak. His job was to watch the heavens carefully so that an up-to-the-minute and accurate star chart could be produced for the new baby. He was also to look out for any dirty stars that might be about, capable of showering bad fortune or ill health on the arrival.

Some contemporary reference manuals for midwives still exist. They were advised to manipulate the birth canal by stretching and pulling. One reference stated that the membranes should be torn out with nails (of the hand). Cutting was common as were fissures after poor suturing, usually with silk.

Breech births are mentioned and also the fact that greater care should be taken when the cord was located around the neck. Tragically many babies and mothers died, possibly as much through panic as poor technique. Caesarean section was well known post mortem to allow for baptism of the child. In the 16th century a Caesarean section was considered entirely possible on a living woman; the first reportedly successful case was in 1500 . Techniques are mentioned in The Birth of Mankind published in the 16th century, but these were only to be used in a life-or-death situation and were recognised as being high-risk for both mother and child. However, these references to Caesarean sections are contentious, as the first properly recorded case in England was not until 1793.

There was much confusion about the purpose of the membranes surrounding the fetus. Many anatomists of the day had theories, most of which were wildly inaccurate and often with names they have invented for conditions or organs, making the analysis of such documents complex. Even the placenta was thought to be a membrane. Midwives had little or no understanding of anatomy and thus struggled to understand the workings of the human body. The role of the uterine muscles in labour was not really appreciated until the mid-18th century; until that time, it was believed that the child pushed itself out. Once the baby was born it is thought that the midwife pulled on the cord to remove the placenta.

A range of stimulants for the new baby are recorded. Rubbing and blowing feature, as might be expected, however salt, wine, honey or even garlic are known to have been put in the baby's mouth.

Much earlier, the often-competent Trotula medical handbook (dating from the 11th or 12th century) did not recommend much medical intervention in birthing but relied on medicines, wine and charms to assist. Suturing is mentioned, however, as are prolapses and how to treat wounds following birth.
The 16th century seems much more aggressive and brutal, and it was not until the late 17th century that authors started to understand that many of the painful and difficult births were actually caused by these harsh practices.

Authors are divided as to the number of children who died at birth, not least because records are so poor across the lower ranks of society and there is also confusion as to the difference between stillbirth and miscarriage in some published papers. The newborn mortality rate seems to hover around $20 \%$, although it is sobering to consider that for Tudor queens across the dynasty this figure was nearer $60 \%$.

\section{Future articles}

Readers may be interested to note that the next article in the series will be on 'The Priest Doctors'.

\section{Acknowledgements}

The author would like to thank the following individuals for their help and advice: Dr R Arnott, Director of the Centre for the History of Medicine, University of Birmingham Medical School, Birmingham and Dr G Williams, Curator of the British Museum, London, UK.

\section{Bibliography}

\section{Primary sources}

The primary sources listed have been reprinted at various times throughout history and although I have only seen sections of them, complete works still exist in specialist libraries such as The Wellcome Library for the History and Understanding of Medicine in London and are certainly worth examining.

1 Trotula. A Medieval Compendium of Women's Medicine. Green Monica $\mathrm{H}$ (ed.) (translated from the Latin). Philadelphia, PA: University of Pennsylvania, 2001. Good root background piece from a Salerno-based female professor of medicine writing in the 11th or 12th century covering the topics of gynaecology, obstetrics, health and hygiene. This translation has a preface that argues input from more than one individual. We do know this text was widely referred to by physicians in Europe.

2 Markham, Gervase (1568?-1637). The English Housewife. Best, Michael R (ed.) (translated from the primary source). Montreal and Kingston, Canada: McGill-Queen's University Press, 1986. A contemporary piece written to advise housewives on wide ranging topics from home medicine to cooking to brewing. The Renaissance woman's handbook.

3 Sadler J. The Sicke Woman's Private Looking Glass. Unknown publisher, 1636

4 Pechey, John (1655-1716). A General Treatise of the Diseases of Maids, Big-bellied Women, Childbed Women, and Widows. Unknown publisher, 1696.

5 Bourgeois, Louise (1563-1636). The Compleat Midwife's Practice Enlarged. London publisher, 1669.

6 Barret, Robert. A Companion for Midwives, Child-bearing Women and Nurses. Unknown publisher, 1699.

7 Unknown author. The Rose Garden of Pregnant Women and Midwives. Strasbourg publisher, 1530 (in German).

8 Turner R. De Morois Foeminers. Unknown publisher, 1686

9 Sharp, Miss Joe. The Midwives Book. Miss Sharp claimed to have 30 years' standing as a midwife (though it is not known whether this is in fact true).

10 Jonas, Richard. The Birth of Mankind. Unknown publisher, 1540. Translated from De Patu Hominus.

\section{Secondary sources}

1 Eccles, Audrey. Obstetrics and Gynaecology in Tudor and Stuart England. London, UK: Croom Helm Ltd, 1982.

2 Copeman WSC. Doctors and Disease in Tudor Times. London, UK: Dawson's of Pall Mall, 1960.

\section{About the Author}

Lesley Smith is an Elizabethan historian, currently studying for the degree of MPhil in the History of Medicine at Birmingham University Medical School. She has appeared in 28 television programmes including Tony Robinson's The Worst Jobs in History.

Lesley is well known as a public speaker, and some readers may have heard her speak at the FFPRHC Current Choices Conference at the Royal Society of Medicine or the Third Annual Conference of the National Chlamydia Screening Programme at the Mermaid Conference Centre, in London in November 2006. 